\title{
Snake Venom Activators of Factor X: An Overview
}

\author{
Guido Tans Jan Rosing \\ Cardiovascular Research Institute Maastricht (CARIM), Maastricht University, \\ Maastricht, The Netherlands
}

\section{Key Words}

Snake venom - Blood coagulation factor $X$. Factor $X$ activator - Metalloprotease $\cdot$ Serine protease

\section{Abstract}

Activators of blood coagulation factor $X$ have been described in the venom of many snake species belonging to the genus Viperidae and Crotalidae as well as from a few Elapid species. Based on the structural and functional properties of purified activating principles, factor $X$ activators are either metalloproteases or serine proteases. The best known activator is RVV-X from Russell's viper (Daboia russelli), a metalloprotease consisting of a heavy chain containing the catalytic domain and two light chains which share homology with C-type lectins and which are thought to exert a regulatory function in the $\mathrm{Ca}^{2+}$-dependent activation of factor $\mathrm{X}$. This activator is also one of the best

\begin{tabular}{ll}
\hline KARGER & ( ) 2002 S. Karger AG, Basel \\
0301-0147/01/0316-0225\$17.50/0 \\
$\begin{array}{l}\text { Fax +4161306 1234 } \\
\begin{array}{l}\text { E-Mail karger@karger.ch } \\
\text { www.karger.com }\end{array}\end{array}$ & $\begin{array}{l}\text { Accessible online at: } \\
\text { www.karger.com/journals/hae }\end{array}$
\end{tabular}

examples of the use of exogenous activators in coagulation research and in addition it is used in many diagnostic research kits. In this paper, an overview is given of the structural and functional properties of snake venom factor $X$ activators thus far described in the literature.

Copyright $@ 2002$ S. Karger AG, Basel

\section{Introduction}

Blood coagulation factor $\mathrm{X}$ is one of the key components of the haemostatic system. Factor $\mathrm{X}$ is synthesized as a single-chain glycoprotein of 488 amino acids including a 40amino-acid pre-pro leader peptide. Upon secretion, the leader sequence is cleaved off, but in addition a tripeptide (Arg-Lys-Arg) is also removed and, thus, the mature protein circulates in the blood as a two-chain protein (fig. 1). The light chain contains $11 \gamma$-carboxyglutamic acid (Gla) residues which are the

G. Tans, PhD, Department of Biochemistry

Cardiovascular Research Institute Maastricht, Maastricht University

PO Box 616, NL-6200 MD Maastricht (The Netherlands)

Tel. +31 433881677, Fax +31433884159

E-Mail g.tans@bioch.unimaas.nl 


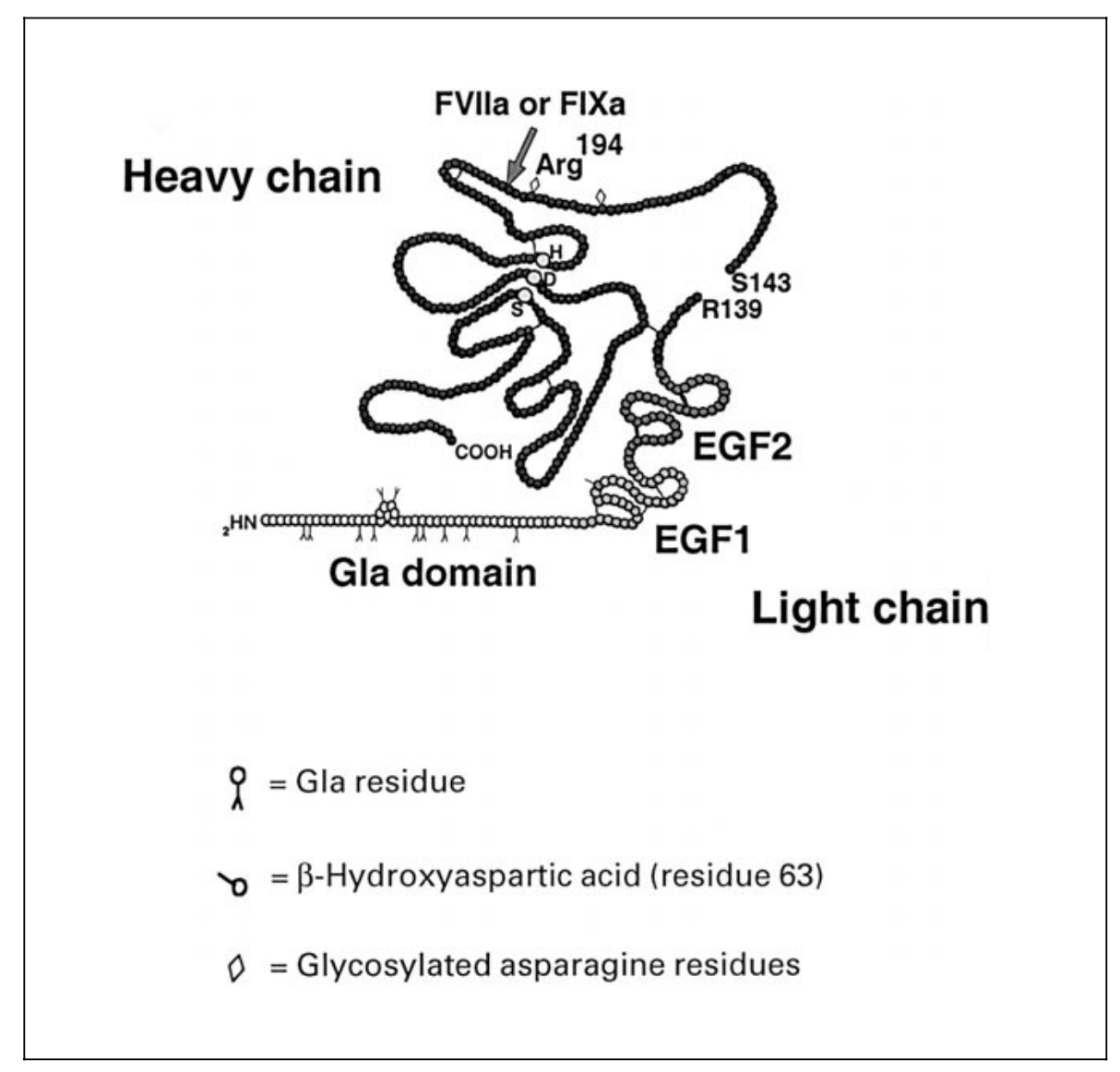

Fig. 1. Schematic representation of the primary sequence and domain structure of blood coagulation factor X. Each circle represents an amino acid residue. The structure is shown without the pre-pro leader sequence and without the tripeptide ( $\operatorname{Arg}^{140}-\mathrm{Lys}^{141}-\mathrm{Arg}^{142}$ ) which connects the heavy chain to the light chain. The catalytic triad (Ser195, His57 and Asp102) is indicated.

result of post-translational carboxylation of specific glutamic acid residues at the aminoterminal end (Gla domain), which are essential for the $\mathrm{Ca}^{2+}$-dependent binding of factor $\mathrm{X}$ (a) to procoagulant (negatively charged) membranes. The Gla domain is followed by two EGF-like domains, the first of which contains a $\beta$-hydroxy aspartic acid residue at position 63 which is also introduced by posttranslational modification. The heavy chain of factor X contains the catalytic triad Ser195His57-Asp102 (chymotrypsin numbering [1]), typical of serine proteases. Activation of factor $\mathrm{X}$ is brought about by cleavage of a single peptide bond at Arg194-Ile195 (fig. 1) which removes the heavily glycosylated first 52 amino-terminal residues of the heavy chain and upon which the active site becomes fully exposed. Under physiological conditions factor $\mathrm{X}$ activation is a membrane-bound process in 
Table 1. Snake species with factor-X-activating principles in the venom

\begin{tabular}{lll}
\hline Species & & Reference \\
\hline Bothrops & atrox, brazili,columbiensis, insularis, marajoensis & 9,11 \\
& cotiara & 10 \\
& erythromelas & $9,10,38$ \\
& alternatus, jararaca, jararacussu, moojeni & 9,10 \\
& n. paranaensis, n. pauloensis, n. urutu & 9,10 \\
& n. neuwiedi, n. diporus, n. matogrossensis & 9 \\
& n. pubescens, pirajai, pradoi, venezuelensis, megaera & 9 \\
Bungarus & fasciatus & 12,39 \\
Cerastes & cerastes, vipera & $8,32,34,35$ \\
Calloselasma & rhodostoma & 8 \\
Daboia ${ }^{\text {E }}$ & russelli russelli, russelli siamensis & 7,8 \\
Echis & carinatus, ocellatus & $8,40,41$ \\
Naja & naja atra & 39 \\
Ophiophagus & hannah & 12,39 \\
Vipera & berus berus, aspis aspis, ammodytes ammodytes lebetina & $8,33,36$ \\
\hline
\end{tabular}

a Only the initial original references are given.

which factor $\mathrm{X}$ is cleaved by the tissue factorfactor VIIa complex during the initiation phase of coagulation via the extrinsic pathway. This initial phase is efficiently attenuated by tissue factor pathway inhibitor (TFPI) but, depending upon the initial strength of the triggering event, the activation of factor $\mathrm{X}$ at the membrane can be sustained by the tenase complex (factor IXa together with factor VIIIa). However, even before the blood coagulation cascade hypothesis was formulated, it was already recognized that certain snake venoms were capable of very efficiently clotting blood [2]. Nowadays, it is recognized that such venoms can contain combinations of activating principles that can initiate and interfere with many steps of the blood coagulation cascade. Indeed, many of the activating principles have greatly facilitated research aimed at understanding and unravelling the mechanism of blood coagulation reactions. One of the targets to initiate or interfere with blood coagulation appears to be at the level of factor $\mathrm{X}$ or factor Xa since many proteins have been identified in snake venoms that are capable of activating factor $\mathrm{X}$ or inhibiting factor Xa. Some of the inhibitors show a remarkable specificity and have been found in blood-sucking animals such as vampire bats [3], ticks [4] or leeches [5, 6].

\section{Snake Venom Activators of Factor $X$}

Since the publication of McFarlane, who was the first to identify a factor $\mathrm{X}$ activating principle in the venom of Russell's viper [7], many other snake venoms were found to contain a factor $\mathrm{X}$ activator. Table 1 gives a comprehensive list of the snake species reported. Factor X activators appear widespread in Viperid and Crotalid venoms and, more recently, a few Elapid venoms were also found to contain factor-X-activating principles. Colu- 
Table 2. Structural and functional properties of purified factor-X-activating principles

\begin{tabular}{|c|c|c|c|c|c|}
\hline Species & Enzyme class & $\mathrm{M}_{\mathrm{r}}$ & Subunits & Cofactor(s) & Inhibitors \\
\hline D. russelli & metalloprotease & 92,880 & $\begin{array}{l}\text { heavy chain } \\
\text { two light chains }\end{array}$ & $\mathrm{Ca}^{2+}$ & chelating agents/PL \\
\hline \multirow[t]{3}{*}{ C. cerastes } & metalloprotease & 75,000 & $\begin{array}{l}\text { heavy chain }{ }^{\mathrm{a}} \\
\text { two light chains }\end{array}$ & $\mathrm{Ca}^{2+}$ & chelating agents/PL \\
\hline & serine protease & 40,000 & two subunits & & DFP \\
\hline & serine protease & 14,000 & single chain & & \\
\hline C. vipera & serine protease & 12,500 & single chain & & PMSF \\
\hline B. atrox & metalloprotease & 75,000 & $\begin{array}{l}\text { heavy chain }{ }^{\mathrm{a}} \\
\text { two light chains }\end{array}$ & $\mathrm{Ca}^{2+}$ & chelating agents \\
\hline V. berus berus & metalloprotease & 38,000 & & $\mathrm{Ca}^{2+}$ & chelating agents \\
\hline$V$. aspis aspis & metalloprotease & 75,000 & multiple chains & $\mathrm{Ca}^{2+}$ & \\
\hline V. lebetina & & $102,000^{\mathrm{b}}$ & $\begin{array}{l}\text { heavy chain } \\
\text { two light chains }\end{array}$ & & \\
\hline O. hannah & serine protease & 64,500 & & $\mathrm{Ca}^{2+}$ & PMSF, TPCK, DFP \\
\hline B. fasciatus & serine protease & 70,000 & & $\mathrm{Ca}^{2+}$ & PMSF, DFP \\
\hline
\end{tabular}

a A heavy chain and two light chains were reported which makes it likely that these activators consist of three subunits.

b Calculated from the $M_{r}$ reported for the heavy chain $(67,000)$ and the two light chains $(16,200$ and 18,800).

brid venoms do not appear to contain factor $\mathrm{X}$ activators because thus far none have been reported and efforts to identify them in venom from Rhabdophis and Dispholidus genera failed [8]. Nahas et al. [9] screened the venom of 26 Bothrops species and found that only six venoms (B. atrox asper, B. cotiara, B. fonsecai, B. ittapetiningae, B. castelnaudi) were not able to activate factor $X[9]$. However, in a later screening Furtado et al. [10] did find a factor $\mathrm{X}$ activator in the venom of $B$. cotiara (especially in young snakes), but not in that of $B$. jararacussu (table 1). Thus, apart from some minor differences reported, the presence of factor $\mathrm{X}$ activators is rather widespread in snake venoms and apparently offers some advantage to the snake in captivating and/or killing its prey. From these many venoms, only a limited number of activating principles have been purified to homogeneity and characterized well. Based on what is known about their functional and physical properties, snake venom factor $\mathrm{X}$ activators are either metalloproteases or serine proteases (table 2). With only a few exceptions, efficient activation of factor $\mathrm{X}$ critically depends upon the presence of $\mathrm{CaCl}_{2}$. Dose-response curves for $\mathrm{CaCl}_{2}$ typically show a sigmoidal dependency with Hill coefficients ranging from 2.4 to 7.9 [11-13]. Since the mechanism of factor $\mathrm{X}$ activation by the activator present in Russell's viper venom (RVV-X) is quite well understood and can be regarded as an example for the other venom activators belonging to the group of metalloproteases, we will describe this activator in more detail. 


\section{The Activator from Russell's Viper Venom}

By far the strongest and most important factor $\mathrm{X}$ activator is the one found in the venom of Russell's viper (Daboia russelli, formerly known as Vipera russelli). Venom preparations of the major two subspecies, i.e $D a$ boia russelli russelli and Daboia russelli siamensis, show potencies that are approximately the same and that are at least ten- to a hundred-fold higher than in any other venom [8]. The purified factor $\mathrm{X}$ activator (RVV-X) contains some $13 \%$ carbohydrate and runs as a single band with 79,000 apparent $M_{r}$ on SDS-PAGE [14]. RVV-X activates factor $X$ by cleaving the Arg-Ile bond at position 194 (cf. fig. 1) and is also able to activate factor IX and protein $\mathrm{C}$ by specific cleavage of Arg-Ile and Arg-Val bonds [14, 15]. The exact molecular weight, sugar composition as well as the composition of the subunit structure following reduction was clarified by Gowda et al. [16] who showed that RVV-X $\left(M_{r}=92,880\right)$ consists of a heavy chain of 57,600 and two light chains of 19,400 and $16,400 \mathrm{M}_{\mathrm{r}}$, respectively, held together by disulfide bond(s). The molecule contains six N-linked oligosaccharides, four of which are located in the heavy chain and one in each light chain. Removal of easily accessible sugars does not appear to change the functional capacity of RVV-X, but removal of the core sugars with $\mathrm{N}$-glycanase causes a virtually complete loss of factor-Xactivating capacity, apparently as a result of major conformational changes in the molecule [17].

The complete amino acid sequence of the heavy chain and the smallest of the two light chains have been determined [18]. The 427residue heavy chain was found to contain three distinct domains: a metalloproteinase domain containing the conserved HExxH metalloprotease catalytic site sequence, a disinte- grin (platelet aggregation inhibitor) domain and a cysteine-rich region, the function of which is as yet not completely clear. The disintegrin domain is presumably responsible for the strong antiplatelet-aggregating effect of RVV-X, although the specific RGD sequence is missing [18]. The light chain (123 residues) shares homology with $\mathrm{C}$-type $\left(\mathrm{Ca}^{2+}\right.$-dependent) lectins and with the anticoagulant proteins factor IX/X binding protein of Trimeresurus flavoviridis $[18,19]$ and factor-X-binding protein of Deinagkistrodon acutus [19]. These latter findings are of great interest and can explain some of the mechanistic properties of RVV-X described earlier. The factorIX/X- and X-binding proteins consist of two C-type lectin subunits held together by a single disulfide bond, probably as the result of domain swapping between the two subunits $[20,21]$. These C-type lectin heterodimers specifically bind to the Gla domain of factor IX and factor $\mathrm{X}$ in a $\mathrm{Ca}^{2+}$-dependent manner $[19,22]$ as a result of which the binding of these clotting factors to negatively charged membranes is likely blocked [23]. Mizuno et al. [23] recently published the crystal structure of the factor-X-binding protein of $D . a c u-$ tus in complex with the Gla domain (residues 1-44) of factor X and showed that the two Ctype lectin domains form a concave region into which the Gla domain of factor X fits by interactions which involve a number of Gla residues and $\mathrm{Ca}^{2+}$ ions that form salt bridges with a cluster of positively charged residues in the factor-X-binding protein.

These data fit well with the model that Morita [24] proposed for RVV-X in which it is supposed that the two C-type lectin light chains of RVV-X serve as an exosite by which RVV-X recognizes and binds to the Gla domain of factor $X$ (fig. 2). From the crystal structure of factor-X-binding protein from $D$. acutus with the Gla domain of factor $\mathrm{X}$, a critical role for $\mathrm{Ca}^{2+}$ ions and Gla residues can be 


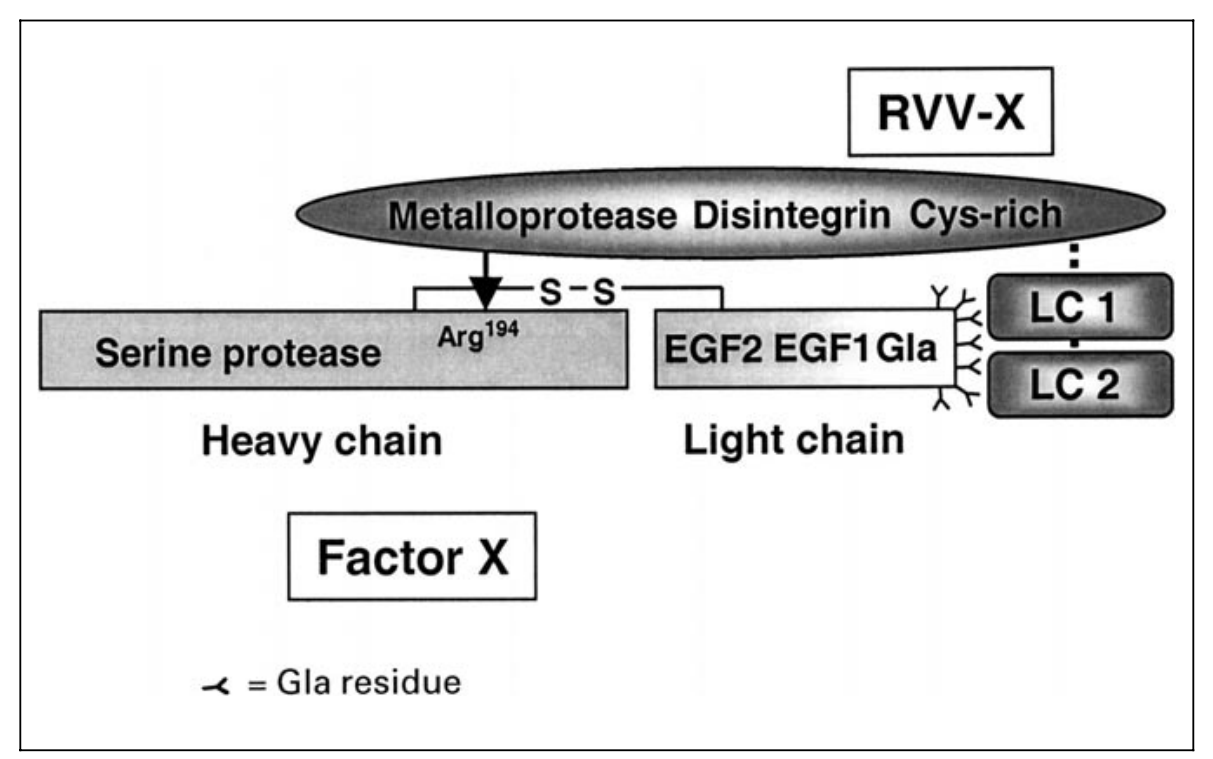

Fig. 2. Mechanism proposed by Morita et al. [24] for the activation of factor X by RVV-X. The heavy chain of RVV-X contains the metalloprotease domain responsible for the proteolytic cleavage of the target bond in factor X. The two C-type lectin light chains (LC1 and LC2) together form a secondary binding site specific for interaction with the Gla domain of factor X. Courtesy of Prof. T. Morita.

inferred which explains why Gla-domainless factor $\mathrm{X}$ or non-carboxylated factor $\mathrm{X}$ are poor substrates for RVV-X [25]. Together with the primary specificity of the metalloprotease domain for hydrophobic and bulky amino acid residues at $\mathrm{P} 1^{\prime}$, which may be extending towards $\mathrm{P}^{\prime}$ and $\mathrm{P}^{\prime}$ ', the presence of such an exosite can further explain the substrate specificity and catalytic efficiency exhibited by RVV-X. Thus, factor $\mathrm{X}$ activation by RVV-X is effectively inhibited by the Gla domain of factor X (residues 1-44) [26] an inhibition that would be unlikely without direct interaction between the Gla domain and an exosite on RVV-X. In addition, RVV-X is capable of efficient activation not only of factor X but also of factor IX and protein C [14, 15], probably as a result of the fact that the Gla domains of these three proteins are very similar [27]. Such a model can also explain earlier findings in which it was reported that activation of bovine factor $\mathrm{X}$ by RVV-X was inhibited by the binding of factor $\mathrm{X}$ to negatively charged lipids [28]. Binding of factor $\mathrm{X}$ to negatively charged lipids involves the Gla domain and will, therefore, by competition diminish the interaction of RVV-X with factor $\mathrm{X}$ resulting in an inhibition of activation.

Finally, the similarity with prothrombin activators such as carinactivase and multactivase should be noted. The properties of these activators in prothrombin activation are similar to those of RVV-X in factor $\mathrm{X}$ activation. Thus, carinactivase and multactivase are also comprised of three subunits (a heavy chain and two light chains) and prothrombin activation by these activators is also critically dependent upon the presence of $\mathrm{Ca}^{2+}$ ions and a 
normally carboxylated prothrombin Gla domain $[29,30]$. Moreover, the isolated regulatory subunits of carinactivase recognize the $\mathrm{Ca}^{2+}$-bound conformation of the prothrombin Gla domain [29] and binding of prothrombin to negatively charged lipids results in inhibition of prothrombin activation [29, 31].

\section{Metalloprotease Activators}

From the snake venom activators that were purified to homogeneity, a number were found to be both structurally and functionally similar to RVV-X (table 2). Although in the original publications concerning the activators purified from $B$. atrox and from Cerastes cerastes venom, it was proposed that the purified activators showed heterogeneity because two light chains were observed on SDS-PAGE $[11,32]$, it is very likely that these activators, like RVV-X, consist of a heavy chain containing the metalloprotease domain and two Ctype lectin light chains held together by disulfide bond(s). Hoffmann and Bon [11] isolated two factor $\mathrm{X}$ activators from $B$. atrox venom, but apart from differences in the purification both activators show similar functional characteristics. In addition, it was noted that these activators cleave the heavy chain of factor $\mathrm{X}$ at two additional positions, an activity not seen with RVV-X. Very recently, an RVV-X like activator was purified from the venom of Vipera lebetina which, like RVV-X, was found capable of activating factor IX [33].

The activators from Cerastes venom deserve special attention. Franssen et al. [32] purified an activator which showed typically the same characteristics as RVV-X, but these authors failed to find other activators. In later publications, however, several other activators were identified which appear to be serine proteases (see below) [34, 35].

Snake Venom Factor X Activators
Vipera berus berus venom may contain several activators and one of these (VBFXAE) was purified to homogeneity and found to be a single-chain glycoprotein of $38,000 \mathrm{M}_{\mathrm{r}}$ [36]. This enzyme, which contains two $\mathrm{Ca}^{2+}$ ions, specifically activates factor $\mathrm{X}$, although a weak hydrolysis of the insulin $B$ chain was noted [36]. The latter activity was inhibited by EDTA, which indicates that this preparation contains a metalloprotease.

Komori et al. [37] purified an activator of $75,000 \mathrm{M}_{\mathrm{r}}$ from Vipera aspis aspis venom which upon reduction showed bands only at 14,000 and $16,000 \mathrm{M}_{\mathrm{r}}$. These authors, therefore, suggested that the activator likely comprises a multitude of these subunits held together by disulfide bonds and the exact subunit composition awaits clarification [37].

\section{Serine Protease Activators}

Until the early 90s, factor X activators had only been identified in Crotalid and Viperid venoms. However, since then specific factor $\mathrm{X}$ activators have also been found in Elapid venoms (table 1,2). These venom activators are enzymes that are quite different from the one found in D. russelli. They appear to be serine proteases since they are inhibited by phenylmethylsulphonyl fluoride (PMSF), diisopropylfluorophosphate (DPF) and chloromethylketones [12, 13]. Moreover, these enzymes are single-chain proteins as judged by SDS-PAGE in the absence and presence of reducing agents $[12,13]$. However, they share with RVV-X an absolute dependence on $\mathrm{Ca}^{2+}$ ions and the effect of $\mathrm{Ca}^{2+}$ on the activation of factor $\mathrm{X}$ is strongly cooperative with Hill coefficients of 6.83 and 7.9 for the activator of Ophiophagus hannah and Bungarus fasciatus, respectively $[12,13]$. Similar activators have been found in venoms from other Bungarus species as well [Kini, R.M., pers. commun., July 12, 2001].

Haemostasis 2001;31:225-233 231 
The activators that were reported in C. cerastes and Cerastes vipera venom are somewhat atypical. Thus far, this has been the only species for which both an RVV-like metalloproteinase and serine protease factor $\mathrm{X}$ activators have been reported. Moreover, a number of the serine proteases reported are rather small (14,000 and $12,500 \mathrm{M}_{\mathrm{r}}$ [35]) when com- pared to the other factor $\mathrm{X}$ activators described. Therefore, final sequence analysis of the various activators present in venom from Cerastes species will be necessary to reveal whether these low $\mathrm{M}_{\mathrm{r}}$ enzymes reflect partially degraded products or whether these truly represent another class of activators.

\section{References}

1 Bode W, Turk D, Karshikov A: The refined 1.9-^̊ X-ray crystal structure of $D$-Phe-Pro-Arg chloromethylketone-inhibited human alpha-thrombin: Structure analysis, overall structure, electrostatic properties, detailed active-site geometry, and structure-function relationships. Protein Sci 1992;1:426-471.

2 Barnett B, Macfarlane RG: On the relative potency of certain snake venoms to coagulate haemophilic blood. Proc Zool Soc Lond 1934;pt 4:977.

3 Fernandez AZ, Tablante A, Beguin S, Hemker HC, Apitz-Castro R: Draculin, the anticoagulant factor in vampire bat saliva, is a tight-binding, noncompetitive inhibitor of activated factor X. Biochim Biophys Acta 1999;1434:135-142.

4 Waxman L, Smith DE, Arcuri KE, Vlasuk GP: Tick anticoagulant peptide (TAP) is a novel inhibitor of blood coagulation factor $\mathrm{Xa}$. Science 1990;248:593-596.

5 Tuszynski GP, Gasic TB, Gasic GJ: Isolation and characterization of antistasin. An inhibitor of metastasis and coagulation. J Biol Chem 1987; 262:9718-9723.

6 Nutt E, Gasic T, Rodkey J, Gasic GJ, Jacobs JW, Friedman PA, Simpson E: The amino acid sequence of antistasin. A potent inhibitor of factor Xa reveals a repeated internal structure. J Biol Chem 1988;263:10162-10167.
7 MacFarlane RG: The coagulant action of Russell's viper venom; the use of antivenom in defining its reaction with a serum factor. $\mathrm{Br} \mathrm{J}$ Haematol 1961;7:496-511.

8 Yamada D, Sekiya F, Morita T: Prothrombin and factor $\mathrm{X}$ activator activities in the venoms of Viperidae snakes. Toxicon 1997;35:15811589.

9 Nahas L, Kamiguti AS, Barros MA: Thrombin-like and factor X-activator components of Bothrops snake venoms. Thromb Haemost 1979;41: 314-328.

10 Furtado MF, Maruyama M, Kamiguti AS, Antonio LC: Comparative study of nine Bothrops snake venoms from adult female snakes and their offspring. Toxicon 1991;29: 219-226.

11 Hofmann H, Bon C: Blood coagulation induced by the venom of $\mathrm{Bo}$ throps atrox. 2. Identification, purification, and properties of two factor $\mathrm{X}$ activators. Biochemistry 1987;26: 780-787.

12 Zhang Y, Xiong YL, Bon C: An activator of blood coagulation factor $\mathrm{X}$ from the venom of Bungarus fasciatus. Toxicon 1995;33:1277-1288.

13 Lee WH, Zhang Y, Wang WY, Xiong YL, Gao R: Isolation and properties of a blood coagulation factor $\mathrm{X}$ activator from the venom of king cobra (Ophiophagus hannah). Toxicon 1995;33:1263-1276.

14 Kisiel W, Hermodson MA, Davie EW: Factor X activating enzyme from Russell's viper venom: Isolation and characterization. Biochemistry 1976;15:4901-4906.
15 Kisiel W, Ericsson LH, Davie EW: Proteolytic activation of protein $\mathrm{C}$ from bovine plasma. Biochemistry 1976;15:4893-4900.

16 Gowda DC, Jackson CM, Hensley $P$, Davidson EA: Factor X-activating glycoprotein of Russell's viper venom. Polypeptide composition and characterization of the carbohydrate moieties. J Biol Chem 1994; 269:10644-10650.

17 Gowda DC, Jackson CM, Kurzban GP, McPhie P, Davidson EA: Core sugar residues of the N-linked oligosaccharides of Russell's viper venom factor $\mathrm{X}$-activator maintain functionally active polypeptide structure. Biochemistry 1996;35: 5833-5837.

18 Takeya H, Nishida S, Miyata T, Kawada S, Saisaka Y, Morita T, Iwanaga $\mathrm{S}$ : Coagulation factor $\mathrm{X}$ activating enzyme from Russell's viper venom (RVV- X). A novel metalloproteinase with disintegrin (platelet aggregation inhibitor)-like and Ctype lectin-like domains. J Biol Chem 1992;267:14109-14117.

19 Atoda H, Yoshida N, Ishikawa M, Morita T: Binding properties of the coagulation factor IX/factor X-binding protein isolated from the venom of Trimeresurus flavoviridis. Eur $\mathrm{J}$ Biochem 1994;224:703-708.

20 Mizuno H, Fujimoto Z, Koizumi M, Kano H, Atoda H, Morita T: Structure of coagulation factors IX/Xbinding protein, a heterodimer of Ctype lectin domains. Nat Struct Biol 1997;4:438-441. 
21 Mizuno H, Fujimoto Z, Koizumi M, Kano H, Atoda H, Morita T: Crystal structure of coagulation factor IXbinding protein from habu snake venom at 2.6 ̊: Implication of central loop swapping based on deletion in the linker region. J Mol Biol 1999; 289:103-112.

22 Sekiya F, Yamashita T, Morita T: Role of calcium(II) ions in the recognition of coagulation factors IX and $\mathrm{X}$ by IX/X-bp, an anticoagulant from snake venom. Biochemistry 1995;34:10043-10047.

23 Mizuno H, Fujimoto Z, Atoda H, Morita T: Crystal structure of an anticoagulant protein in complex with the Gla domain of factor X. Proc Natl Acad Sci USA 2001;98:72307234.

24 Morita T: Proteases which activate factor X; in Bailey G (ed): Enzymes from Snake Venoms. Fort Collins, Alaken, 1998, pp 179-209.

25 Skogen WF, Bushong DS, Johnson AE, Cox AC: The role of the Gla domain in the activation of bovine coagulation factor $\mathrm{X}$ by the snake venom protein XCP. Biochem Biophys Res Commun 1983;111:1420.

26 Morita T, Atoda H, Sekiya F: Structure and functions of coagulation factor IX/factor X-binding protein isolated from the venom of Trimeresurus flavoviridis. Adv Exp Med Biol 1996;391:187-196.

27 Furie B, Bouchard BA, Furie BC: Vitamin K-dependent biosynthesis of gamma-carboxyglutamic acid. Blood 1999;93:1798-808.
28 van Dieijen G, Tans G, van Rijn J, Zwaal RF, Rosing J: Simple and rapid method to determine the binding of blood clotting factor $\mathrm{X}$ to phospholipid vesicles. Biochemistry 1981;20:7096-7101.

29 Yamada D, Sekiya F, Morita T: Isolation and characterization of carinactivase, a novel prothrombin activator in Echis carinatus venom with a unique catalytic mechanism. J Biol Chem 1996;271:5200-5207.

30 Petrovan RJ, Govers-Riemslag JW, Nowak G, Hemker HC, Rosing J, Tans G: Purification and characterization of multisquamase, the prothrombin activator present in Echis multisquamatus venom. Thromb Res 1997;88:309-316.

31 Govers-Riemslag JW, Johnsen L, Petrovan RJ, Rosing J, Tans G: A kinetic assay to determine prothrombin binding to membranes. Thromb Res 1998;92:239-247.

32 Franssen JH, Janssen-Claessen T, Van Dieijen G: Purification and properties of an activating enzyme of blood clotting factor $\mathrm{X}$ from the venom of Cerastes cerastes. Biochim Biophys Acta 1983;747:186-190.

33 Siigur E, Tõnismägi K, Trummal K, Aaspõllu A, Vija H, Subbi J, Siigur $\mathrm{J}$ : Factor X activator from Vipera lebetina snake venom with factor IX activating activity. Thromb Haemost 2001;suppl:P2108.
34 el-Asmar MF, Shaban E, Hagag M, Swelam N, Tu A: Coagulant component in Cerastes cerastes (Egyptian sand viper) venom. Toxicon 1986; 24:1037-1044.

35 Farid T, Nasser H, Zaki K, el-Asmar MF: Low molecular weight factor X activator from Cerastes vipera (Sahara sand viper) venom. Toxicon 1993;31:1007-1017.

36 Samel M, Siigur J: Medium molecular weight factor $\mathrm{X}$ activating enzyme from Vipera berus berus venom. Toxicon 1995;33:41-52.

37 Komori Y, Nikai T, Sugihara H: Isolation and characterization of factor $\mathrm{X}$ activator from the venom of $\mathrm{Vi}$ pera aspis aspis. Int J Biochem 1990; 22:1053-1060.

38 Maruyama M, Kamiguti AS, Tomy SC, Antonio LC, Sugiki M, Mihara $\mathrm{H}$ : Prothrombin and factor X activating properties of Bothrops erythromelas venom. Ann Trop Med Parasitol 1992;86:549-556.

39 Zhang Y, Xiong YL, Bon C: Effects of Chinese snake venoms on blood coagulation, coagulation factors and synthetic substrates. Asiat Herpetol Res 1993;5:117-126.

40 Denson KW: Clot-inducing substances present in snake venoms with particular reference to Echis carinatus. Thromb Res 1976;8:351360.

41 Hemker HC, van Dam-Mieras MC, Devilee PP: The action of Echis carinatus venom on the blood coagulation system. Demonstration of an activator of factor X. Thromb Res 1984;35:1-9. 